\title{
Pathways of arginine biosynthesis in extreme thermophilic archaeo- and eubacteria
}

\author{
Mark Van de Casteele, ${ }^{1}$ Marc Demarez, ${ }^{2}$ Christiane Legrain, ${ }^{2}$ Nicolas Glansdorff ${ }^{1,2}$ \\ and ANDRÉ PIÉRARD ${ }^{2,3 *}$ \\ ${ }^{1}$ Laboratorium voor Erfelijkheidsleer en Microbiologie, Vrije Universiteit Brussel \\ ${ }^{2}$ Institut de Recherches du CERIA and ${ }^{3}$ Laboratoire de Microbiologie, Faculté des Sciences, Université Libre de \\ Bruxelles, 1 avenue Emile Gryson, B-1070 Brussels, Belgium
}

(Received 2 January 1990; revised 9 February 1990; accepted 27 February 1990)

\begin{abstract}
The pathway of arginine biosynthesis was investigated in two thermophilic eubacteria, Thermus aquaticus and Thermotoga maritima, and in two thermophilic archaeobacteria, Sulfolobus solfataricus and Pyrococcus furiosus. In the first three organisms, arginine biosynthesis proceeds via $\boldsymbol{N}$-acetylated intermediates as in mesophilic microorganisms. Only the enzymes catalysing the three last steps of the pathway could be detected in $P$. furiosus. The two eubacterial strains possess an ornithine acetyltransferase and are thus able to recycle the acetyl group from acetylornithine to glutamate. The archaeobacterium, $S$. solfataricus, uses the linear pathway in which the formation of ornithine is mediated by the hydrolytic enzyme acetylornithinase. Repression of enzyme synthesis by arginine was observed for most of the enzymes tested in $T$. aquaticus and $S$. solfataricus. Feedback inhibition by arginine was shown only on the ornithine acetyltransferase from $T$. aquaticus. This inhibition pattern is of interest since it would be the first example of control of arginine biosynthesis at this particular step. Data concerning the thermal stability of the arginine biosynthetic enzymes are presented.
\end{abstract}

\section{Introduction}

The biosynthesis of arginine has been extensively investigated in mesophilic micro-organisms (for a review, see Cunin et al., 1986). This biosynthesis proceeds from glutamate in eight enzymic steps: five steps involving $\mathrm{N}$-acetylated intermediates lead to ornithine which is converted into arginine through three further steps (Fig. 1). Whereas the intermediates of this sequence are identical in all micro-organisms, there are significant differences with respect to the reaction steps involved and to the regulation of the pathway. Enterobacteriaceae and Bacillaceae use a linear pathway in which the formation of ornithine is mediated by the hydrolytic enzyme acetylornithinase. The other prokaryotes, several methanogenic archaeobacteria (Meile \& Leisinger, 1984) and all eukaryotic microbes have been found to recycle the acetyl group by transacetylation of $\mathrm{N}$-acetylornithine and glutamate (an energetically more economical version of arginine biosynthesis). The sixth step of arginine biosynthesis, the conversion of ornithine into citrulline, uses carbamoylphosphate, a highly thermolabile precursor (half-life at neutral $\mathrm{pH}$ in aqueous solution: about $1 \mathrm{~min}$ at $65^{\circ} \mathrm{C}$ and $<1 \mathrm{~s}$ at
$100{ }^{\circ} \mathrm{C}$ ), also required in pyrimidine biosynthesis. The involvement of such a thermolabile intermediate in the metabolism of extreme thermophilic micro-organisms raises the question of the mechanisms used to either bypass carbamoylphosphate or protect it from decomposition at their growth temperatures.

As part of a study of carbamoylphosphate metabolism in thermophilic micro-organisms, we have investigated the pathway through which arginine is synthesized in two thermophilic eubacteria, Thermus aquaticus and Thermotoga maritima, and two thermophilic archaeobacteria, Sulfolobus solfataricus and Pyrococcus furiosus. The optimal growth temperature of $T$. aquaticus is $70^{\circ} \mathrm{C}$ in minimal medium; the optimal temperatures of $T a$. maritima, $S$. solfataricus and $P$. furiosus are only available for rich media and are 80,85 and $100{ }^{\circ} \mathrm{C}$, respectively (Huber et al., 1986; Fiala \& Stetter, 1986). Two of these micro-organisms, Ta. maritima and $P$. furiosus, are obligate anaerobes. Ta. maritima is the most thermophilic eubacterium presently known (Huber et al., 1986). In the phylogenetic tree based upon 16S rRNA sequence comparisons, it represents the oldest and most slowly evolving branch within the eubacteria (Woese, 1987). $S$. solfataricus is a thermoacidophilic archaeobacterium, 
while $P$. furiosus belongs to the so-called 'hyperthermophiles' that grow optimally around $100^{\circ} \mathrm{C}$ (Stetter, 1986).

Partial results were reported in abstract form in Degryse et al. (1976) and Legrain et al. (1989).

\section{Methods}

Bacterial strains. Thermus aquaticus ZO5 was isolated by Degryse $e t$ al. (1978). Sulfolobus solfataricus was obtained from the American Type Culture Collection (ATCC 35091). Thermotoga maritima MSB8 and Pyrococcus furiosus Vcl (DSM 3638) were kindly provided by Professor K. O. Stetter, Regensburg, FRG.

Culture conditions. T. aquaticus was grown in liquid mineral medium 162 (Degryse et al., 1978) supplemented with $20 \mathrm{mM}$-sodium pyruvate and $5 \mathrm{mM}-\left(\mathrm{NH}_{4}\right)_{2} \mathrm{SO}_{4}$. Cultures were grown at $65^{\circ} \mathrm{C}$ with shaking at 200 r.p.m. S. solfataricus was grown in medium containing $3 \cdot 1 \mathrm{~g}$

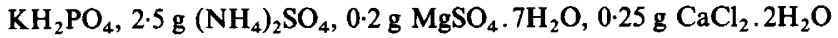
and either $2 \mathrm{~g}$ yeast extract (Difco) or $3 \mathrm{~g}$ glucose in 1 litre of distilled water. Cultures were grown at $80^{\circ} \mathrm{C}$ with shaking at 200 r.p.m. The anaerobic strains, Ta. maritima and $P$. furiosus, were cultivated using the technique of Balch \& Wolfe (1976). Cultures $(40 \mathrm{ml})$ were grown in stoppered $120 \mathrm{ml}$ serum bottles pressurized with $\mathrm{N}_{2}(200 \mathrm{kPa})$ and incubated without agitation. Larger scale cultures were grown in a 15 litre fermentor (Biolafitte) under $\mathrm{N}_{2}\left(400 \mathrm{ml} \mathrm{min}{ }^{-1}\right)$ with gentle stirring (100 r.p.m.). Bacterial growth was determined by direct count. Unless otherwise specified, Ta. maritima was grown at $80^{\circ} \mathrm{C}$ in 'MMS'medium (Huber et al., 1986). P. furiosus was cultivated at $95^{\circ} \mathrm{C}$ in 'SME'-medium (Stetter et al., 1983; Fiala et al., 1986). Cultures (15 litres) were grown in the absence of elemental sulphur.

Preparation of cell extracts. T. aquaticus and S. solfataricus cells from exponential phase cultures were harvested by centrifugation ( $10 \mathrm{~min}$, $7000 \mathrm{~g}$ ) and washed in $0.9 \%(\mathrm{w} / \mathrm{v}) \mathrm{NaCl}$. Ta. maritima and $P$. furiosus were harvested in the late exponential phase (about $2 \times 10^{8}$ cells ml $^{-1}$ ) and washed in their respective mineral media. Unless otherwise specified, cells were suspended in $50 \mathrm{~mm}-\mathrm{Tris} / \mathrm{HCl}$ buffer $(\mathrm{pH} 8.0)$ and disrupted by sonication for $5 \mathrm{~min}$ in a Heat Systems ultrasonic oscillator $(100 \mathrm{~W}, 20 \mathrm{kHz})$. After sonication, the resulting suspension was centrifuged $(15 \mathrm{~min}, 20000 \mathrm{~g})$. All these operations were done below $10{ }^{\circ} \mathrm{C}$. The supernatant was used for enzyme assays. For arginine inhibition experiments the crude extracts were either dialysed overnight against the extraction buffer or passed through a Sephadex G-25 column.

Enzyme assays. Ornithine carbamoyltransferase activity was measured at $55^{\circ} \mathrm{C}$ because of the thermal lability of carbamoylphosphate. Carbamoylphosphate synthetase activity was measured at $60^{\circ} \mathrm{C}$. All the other assays were done at $65^{\circ} \mathrm{C}$ for $T$. aquaticus enzymes and at $70^{\circ} \mathrm{C}$ for enzymes from the other organisms.

$\mathrm{N}$-Acetylglutamate synthase was measured by a radioassay using $\mathrm{L}-\left[{ }^{14} \mathrm{C}\right]$ glutamate as substrate. $\mathrm{N}$-Acetylglutamate was isolated by high voltage paper electrophoresis. The reaction mixture contained, in a final volume of $50 \mu \mathrm{l}: 100 \mathrm{mM}-\mathrm{Tris} / \mathrm{HCl}$ buffer $(\mathrm{pH} 8.0), 20 \mathrm{mM}-\mathrm{L}-$ $\left[{ }^{14} \mathrm{C}\right]$ glutamate $\left[1 \mu \mathrm{Ci} \mu \mathrm{mol}^{-1}\left(37 \mathrm{kBq} \mu \mathrm{mol}^{-1}\right)\right], 2 \mathrm{~mm}$-acetyl-CoA and extract $(0.2-0.5 \mathrm{mg}$ protein). The incubation was started by the addition of acetyl-CoA and, after $30 \mathrm{~min}$, terminated by the addition of $10 \mu 110 \%(\mathrm{w} / \mathrm{v})$ trichloroacetic acid. Precipitated protein was removed by centrifugation. Samples $(10 \mu \mathrm{l})$ were spotted on to Whatman $3 \mathrm{MM}$ paper and subjected to high voltage electrophoresis in water/formic acid/acetic acid $\left(910: 30: 60\right.$, by vol.) at $100 \mathrm{~V} \mathrm{~cm}^{-1}$ for $20 \mathrm{~min}$. The positions of glutamate and $\mathrm{N}$-acetylglutamate on the electrophoretograms were deduced from those of reference standards. Glutamate was localized by spraying with ninhydrin reagent and $N$-acetylglutamate by soaking in $0.01 \%(\mathrm{w} / \mathrm{v})$ bromocresol green in acetone made alkaline with $\mathrm{N}$-ethylmorpholine. The sample areas corresponding to $\mathrm{N}$ acetylglutamate and glutamate were cut out and the radioactivity measured by liquid scintillation counting in toluene containing $5 \mathrm{~g}$ PPO $\mathrm{1}^{-1}$. Formation of $\mathrm{N}$-acetylglutamate was a linear function of time up to $40 \mathrm{~min}$ incubation.

$N$-Acetylglutamate 5-phosphotransferase was measured by the ferric chloride method. The incubation mixture consisted of: $200 \mathrm{~mm}$ Tris/ $\mathrm{HCl}$ buffer (pH 8.0), $40 \mathrm{~mm}$ - $N$-acetylglutamate, $40 \mathrm{~mm}-\mathrm{MgCl}_{2}$, $40 \mathrm{~mm}-\mathrm{ATP}, 400 \mathrm{~mm}-\mathrm{NH}_{2} \mathrm{OH}(\mathrm{pH} 8.0)$ and extract $(0.1-0.5 \mathrm{mg}$ protein) in a final volume of $0.5 \mathrm{ml}$. The reaction was started by the addition of $\mathrm{N}$-acetylglutamate and terminated by the addition of $1.0 \mathrm{ml}$ of $1.0 \mathrm{M}-\mathrm{HCl}$ containing $5 \%(\mathrm{w} / \mathrm{v}) \mathrm{FeCl}_{3} .6 \mathrm{H}_{2} \mathrm{O}$ and $4 \%(\mathrm{w} / \mathrm{v})$ trichloroacetic acid. The absorbance of the hydroxamate- $\mathrm{Fe}^{3+}$ complex was measured at $500 \mathrm{~nm}$. Formation of $\mathrm{N}$-acetylglutamyl 5hydroxamate was a linear function of time up to $120 \mathrm{~min}$ incubation.

Acetylornithinase was measured by the method of Vogel \& McLellan (1970). The protein concentration was about $0.2 \mathrm{mg} \mathrm{ml}^{-1}$ in the assay and the incubation time $10 \mathrm{~min}$.

Ornithine acetyltransferase was determined by a radioassay similar to that described for $N$-acetylglutamate synthase, but with $N$ acetylornithine instead of acetyl-CoA. The reaction mixture contained, in a final volume of $50 \mu \mathrm{l}: 100 \mathrm{~mm}-\mathrm{Tris} / \mathrm{HCl}(\mathrm{pH} 8.0), 40 \mathrm{~mm}-\mathrm{L}-$ $\left[{ }^{14} \mathrm{Clglutamate}\left[1 \mu \mathrm{Ci} \mu \mathrm{mol}^{-1}\left(37 \mathrm{kBq} \mu \mathrm{mol}^{-1}\right)\right], 20 \mathrm{~mm}-N\right.$-acetylornithine and extract (about $0.5 \mathrm{mg}$ protein). The incubation time was $30 \mathrm{~min}$.

Ornithine carbamoyltransferase was assayed by measuring the formation of citrulline as described by Stalon et al. (1972). The $S$. solfataricus enzyme was assayed in a reaction mixture containing, in a final volume of $2.0 \mathrm{ml}: 80 \mathrm{mM}-\mathrm{EDTA} / \mathrm{NaOH}$ buffer $(\mathrm{pH} 7.8), 15 \mathrm{mM}$ ornithine, $10 \mathrm{~mm}$-carbamoylphosphate and extract. Ornithine carbamoyltransferases from the other organisms were assayed in a reaction mixture containing : $200 \mathrm{~mm}$-Tris/ $\mathrm{HCl}$ buffer ( $\mathrm{pH} \mathrm{8.0),} 2$ mM-ornithine, $10 \mathrm{~mm}$-carbamoylphosphate and extract. Protein concentration was about $0.5 \mathrm{mg} \mathrm{ml}^{-1}$ in the assay and the incubation time $5 \mathrm{~min}$. Formation of citrulline was linear during this time.

Argininosuccinate synthetase was assayed by a modification of the method of Haas et al. (1977), using $\mathrm{L}-\left[{ }^{14} \mathrm{C}\right]$ citrulline as a substrate. $\mathrm{L}$-Argininosuccinate was converted to its anhydride at acidic $\mathrm{pH}$ and isolated by high voltage paper electrophoresis. The reaction mixture contained, in a final volume of $50 \mu \mathrm{l}: 60 \mathrm{mM}$-Tris/ $\mathrm{HCl}$ (pH 8.7), $10 \mathrm{mM}$ sodium L-aspartate, $10 \mathrm{~mm}$-sodium ATP, $10 \mathrm{mM}-\mathrm{MgCl}_{2}, 2 \mathrm{mM}-\mathrm{L}$ [ureido ${ }^{14} \mathrm{C}$ ]citrulline $\left[3 \mu \mathrm{Ci} \mu \mathrm{mol}^{-1}\left(111 \mathrm{kBq} \mu \mathrm{mol}^{-1}\right)\right.$ ], extract $(0.2-$ $0.5 \mathrm{mg}$ protein) and $200 \mathrm{~mm}$-sodium fumarate. The incubation was terminated by the addition of $20 \mu 11.5 \mathrm{M}$-formic acid. The samples were boiled for $15 \mathrm{~min}$ and precipitated protein was removed by centrifugation. Samples $(10 \mu \mathrm{l})$ were spotted on to Whatman $3 \mathrm{MM}$ paper and subjected to high voltage electrophoresis in water/formic acid/acetic acid $\left(910: 30: 60\right.$, by vol.) at $100 \mathrm{~V} \mathrm{~cm}^{-1}$ for $15 \mathrm{~min}$. The positions of citrulline, argininosuccinate, argininosuccinic anhydride and arginine on the electrophoretograms were deduced from those of reference standards, localized by spraying with ninhydrin reagent. The corresponding sample areas were cut out and the radioactivity measured by liquid scintillation counting in toluene containing $5 \mathrm{~g}$ PPO $\mathrm{1}^{-1}$. Formation of argininosuccinate was a linear function of time up to $30 \mathrm{~min}$ incubation.

Argininosuccinase was assayed by the procedure of Theil $e t$ al. (1969). Protein concentration was about $1 \mathrm{mg} \mathrm{ml}^{-1}$ in the assay and the incubation time $20 \mathrm{~min}$.

Carbamoylphosphate synthetase was measured by the method of Piérard et al. (1972). The reaction mixture contained, in a volume of $1.0 \mathrm{ml}: 100 \mathrm{~mm}$-Tris/ $\mathrm{HCl}$ (pH 9.0), $10 \mathrm{~mm}$-sodium ATP, $10 \mathrm{~mm}$ $\mathrm{MgCl}_{2}, 6 \mathrm{mM}-\mathrm{L}$-ornithine, $20 \mathrm{mM}-\mathrm{NaH}^{14} \mathrm{CO}_{3} \quad\left[0 \cdot 2 \mu \mathrm{Ci} \mu \mathrm{mol}^{-1}\right.$ $\left.\left(7.4 \mathrm{kBq} \mu \mathrm{mol}^{-1}\right)\right], 200$ units of partially purified ornithine carbamoyltransferase from $E$. coli, crude extract $(0.5-2.0 \mathrm{mg}$ protein) and either 
$20 \mathrm{~mm}$-L-glutamine or $100 \mathrm{mM}-\mathrm{NH}_{4} \mathrm{Cl}$. The reaction was stopped by the addition of $1 \mathrm{ml} \mathrm{0.25} \mathrm{M}$-trichloroacetic acid. Excess $\mathrm{NaH}^{14} \mathrm{CO}_{3}$ was removed and $\left[{ }^{14} \mathrm{C}\right.$ citrulline determined as described by Piérard et al. (1972). Enzyme activity was a linear function of incubation time up to $20 \mathrm{~min}$ and of protein concentration below $2 \mathrm{mg} \mathrm{ml}^{-1}$.

One enzyme unit is defined as the amount of enzyme that converts $1 \mu$ mol substrate to product $h^{-1}$. Protein concentrations were determined by the Lowry method.

\section{Results}

\section{In vitro assay of enzyme activities}

$\mathrm{N}$-Acetylglutamate synthase and $\mathrm{N}$-acetylglutamate 5phosphotransferase activities (Fig. 1, steps 1 and 2) were detected in three of the four strains examined (Table 1). The specific activities of these two enzymes were comparable to those reported for mesophilic bacteria (Udaka, 1966; Haas et al., 1972; Leisinger \& Haas, 1975; Abdelal \& Nainan, 1979). These two activities could not be detected in $P$. furiosus extracts. $N$-Acetylglutamate-5semialdehyde dehydrogenase and $N^{2}$-acetylornithine 5aminotransferase activities (Fig. 1, steps 3 and 4), for which no reliable high temperature assays are available, were not measured.

Two enzymes, acetylornithinase (Fig. 1, step 5) and ornithine acetyltransferase (Fig. 1, step $5^{\prime}$ ), can convert $N^{2}$-acetylornithine to ornithine. Ornithine acetyltransferase activity was found in T. aquaticus and Ta. maritima extracts, but could not be detected in $S$. solfataricus and $P$. furiosus extracts (Table 1). The $K_{\mathrm{m}}$ value for $N^{2}$. acetylornithine at $10 \mathrm{~mm}$-glutamate was $0.5 \mathrm{mM}$ for the T. aquaticus enzyme and $2 \mathrm{~mm}$ for the Ta. maritima enzyme. In $S$. solfataricus, acetylornithine was deacetylated by the hydrolytic enzyme acetylornithinase. A low level of an acetylornithinase with a poor affinity for acetylornithine $\left(K_{\mathrm{m}}>40 \mathrm{~mm}\right)$ was found in $T$. aquaticus extracts. A very small amount of acetylornithinase activity was also detected in Ta. maritima. The latter two activities probably result from deacetylation of ornithine by non-specific enzymes (see Discussion).

The last three enzymes of arginine biosynthesis, ornithine carbamoyltransferase, argininosuccinate synthetase and argininosuccinase, were detected in the four strains examined (Table 1). The high levels of ornithine carbamoyltransferase activity measured in the two archaeobacteria were comparable to those described for methanogenic archaeobacteria (Meile \& Leisinger, 1984).

\section{Repression of enzyme formation by arginine}

In $T$. aquaticus, the synthesis of all the arginine biosynthetic enzymes, except $N$-acetylglutamate 5-phos-

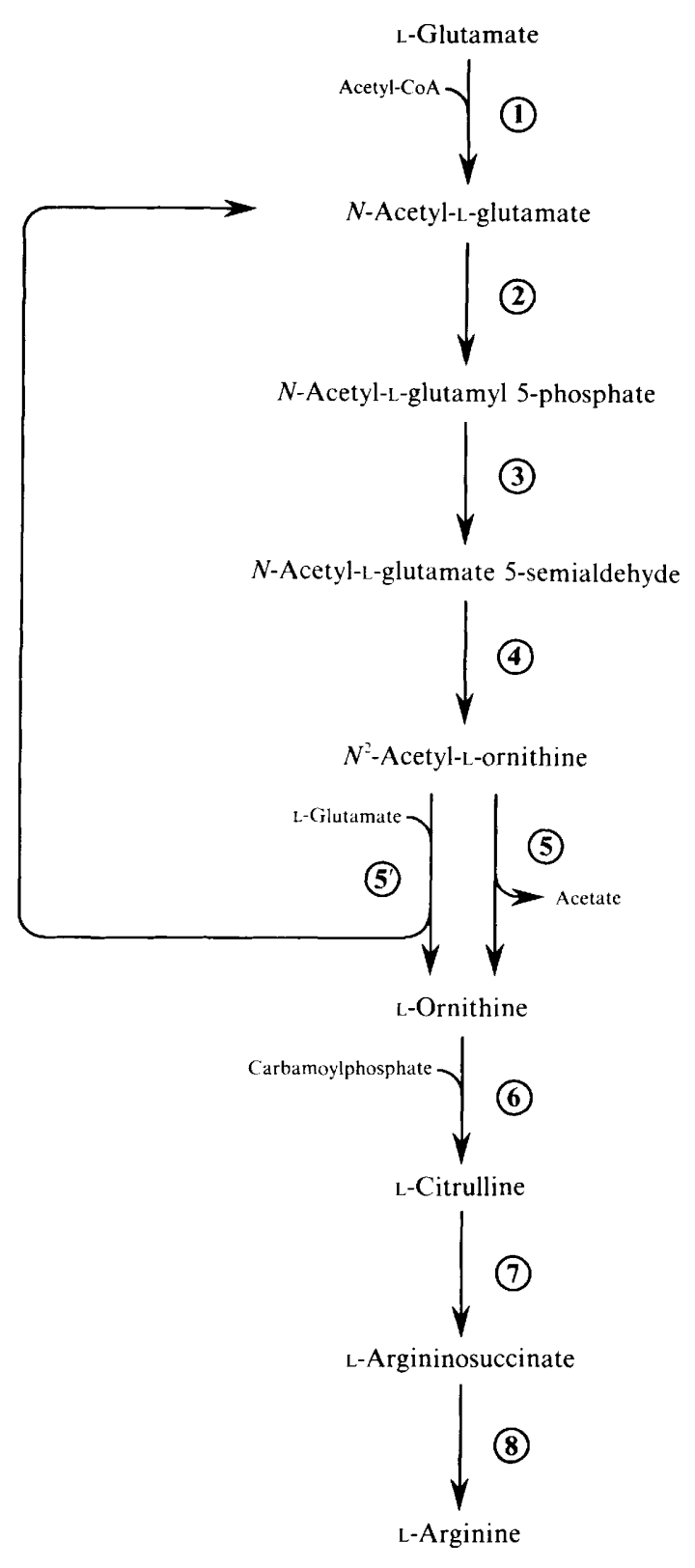

Fig. 1. Arginine biosynthesis. 1, $\mathrm{N}$-Acetylglutamate synthase (acetylCoA : L-glutamate $N$-acetyltransferase; EC 2.3.1.1);2, $N$-acetylglutamate 5-phosphotransferase (ATP: $N$-acetyl-L-glutamate 5-phosphotransferase; EC 2.7.2.8); 3, $N$-acetylglutamate 5-semialdehyde dehydrogenase [ $N$-acetyl-L-glutamate-5-semialdehyde: NADP+ 5-oxidoreductase (phosphorylating); EC 1.2.1.38]; 4, $N^{2}$-acetylornithine 5aminotransferase $\left(N^{2}\right.$-acetyl-L-ornithine:2-oxoglutarate aminotransferase; EC 2.6.1.11); 5, acetylornithinase ( $N^{2}$-acetyl-L-ornithine amidohydrolase; EC 3.5.1.16); $5^{\prime}$ ornithine acetyltransferase $\left(N^{2}-\right.$ acetyl-L-ornithine:L-glutamate $N$-acetyltransferase; EC 2.3.1.35); 6 , ornithine carbamoyltransferase (carbamoylphosphate : $L$-ornithine carbamoyltransferase; EC 2.1.3.3); 7, argininosuccinate synthetase [L-citrulline:L-aspartate ligase (AMP-forming); EC 6.3.4.5]; 8, argininosuccinase (L-argininosuccinate arginine-lyase; EC 4.3.2.1). 
Table 1. Specific activities of arginine biosynthetic enzymes in extreme thermophilic bacteria

Specific activities are means of at least two measurements made on independent cultures. The values for replicate assays differed from the mean by $<20 \%$ for $\mathrm{N}$-acetylglutamate synthase, ornithine acetyl transferase and argininosuccinate synthetase, and by $<10 \%$ for the other activities. ND, Not determined.

\begin{tabular}{|c|c|c|c|c|c|c|c|c|}
\hline \multirow[b]{2}{*}{ Strain } & \multirow[b]{2}{*}{$\begin{array}{l}\text { Addition } \\
\text { to minimal } \\
\text { growth } \\
\text { medium* }\end{array}$} & \multicolumn{7}{|c|}{ Enzyme activity [units (mg protein) $)^{-1}$ ] } \\
\hline & & $\begin{array}{l}N \text {-Acetyl- } \\
\text { glutamate } \\
\text { synthase }\end{array}$ & $\begin{array}{l}N \text {-Acetyl- } \\
\text { glutamate } \\
\text { 5-phospho- } \\
\text { transferase }\end{array}$ & $\begin{array}{c}\text { Acetyl- } \\
\text { ornithinase }\end{array}$ & $\begin{array}{l}\text { Ornithine } \\
\text { acetyl- } \\
\text { transferase }\end{array}$ & $\begin{array}{l}\text { Ornithine } \\
\text { carbamoyl- } \\
\text { transferase }\end{array}$ & $\begin{array}{l}\text { Arginino- } \\
\text { succinate } \\
\text { synthetase }\end{array}$ & $\begin{array}{l}\text { Arginino- } \\
\text { succinase }\end{array}$ \\
\hline $\begin{array}{l}\text { Thermus } \\
\text { aquaticus }\end{array}$ & $\begin{array}{l}\text { pyr, } \mathrm{NH}_{4}^{+} \\
\text {pyr, } \mathbf{N H}_{4}^{+} \text {, arg }\end{array}$ & $\begin{array}{l}0 \cdot 14 \\
0 \cdot 07\end{array}$ & $\begin{array}{l}0.45 \\
0.46\end{array}$ & $\begin{array}{l}0 \cdot 6 \\
\text { ND }\end{array}$ & $\begin{array}{l}0 \cdot 34 \\
0 \cdot 13\end{array}$ & $\begin{array}{l}3 \cdot 5 \\
0 \cdot 3\end{array}$ & $\begin{array}{l}0.39 \\
0.07\end{array}$ & $\begin{array}{l}1.33 \\
0 \cdot 29\end{array}$ \\
\hline $\begin{array}{l}\text { Thermotoga } \\
\text { maritima }\end{array}$ & $\begin{array}{l}\text { Starch, YE } \\
\text { Starch, YE, arg }\end{array}$ & $\begin{array}{l}0.45 \\
0.45\end{array}$ & $\begin{array}{l}0 \cdot 15 \\
0 \cdot 10\end{array}$ & $\begin{array}{l}0.02 \\
\text { ND }\end{array}$ & $\begin{array}{l}0 \cdot 35 \\
0 \cdot 35\end{array}$ & $\begin{array}{l}9 \cdot 3 \\
8 \cdot 3\end{array}$ & $\begin{array}{l}0.041 \\
0 \cdot 026\end{array}$ & $\begin{array}{l}0.03 \\
\text { ND }\end{array}$ \\
\hline $\begin{array}{l}\text { Sulfolobus } \\
\text { solfataricus }\end{array}$ & $\begin{array}{l}\text { glc, } \mathrm{NH}_{4}^{+} \\
\text {glc, } \mathrm{NH}_{4}^{+}, \text {arg } \\
\text { YE } \\
\text { YE, arg }\end{array}$ & $\begin{array}{l}0 \cdot 11 \\
0 \cdot 10 \\
0 \cdot 12 \\
0 \cdot 10\end{array}$ & $\begin{array}{l}0 \cdot 18 \\
0.06 \\
0.05 \\
0.05\end{array}$ & $\begin{array}{l}7.6 \\
7.8 \\
8.9 \\
8 \cdot 0\end{array}$ & $\begin{array}{l}<0.001 \\
\quad \text { ND } \\
<0.001 \\
<0.001\end{array}$ & $\begin{array}{r}15 \cdot 3 \\
5 \cdot 0 \\
7 \cdot 2 \\
4 \cdot 3\end{array}$ & $\begin{array}{l}0.040 \\
0.016 \\
0.027 \\
0.014\end{array}$ & $\begin{array}{l}0 \cdot 34 \\
0 \cdot 10 \\
0 \cdot 18 \\
0 \cdot 07\end{array}$ \\
\hline $\begin{array}{l}\text { Pyrococcus } \\
\text { furiosus }\end{array}$ & pep, YE & $<0.001$ & $<0.02$ & $<0.005$ & $<0.001$ & $26 \cdot 0$ & $0 \cdot 014$ & $0 \cdot 20$ \\
\hline
\end{tabular}

* pyr, pyruvate (20 mM); glc, glucose (20 mM); YE, yeast extract (Ta. maritima, $0.05 \%$; S. solfataricus, $0.2 \% ; P$. furiosus, $0 \cdot 1 \%) ;$ pep, peptone $(0 \cdot 5 \%)$; arg, arginine ( $5 \mathrm{mM}$ ). The $\mathrm{NH}_{4}^{+}$concn was $5 \mathrm{mM}$. The arginine concn in $0 \cdot 1 \%$ YE was about $0.1 \mathrm{mM}$.

photransferase, was repressed by arginine. The repression ratios ranged from 2 for $\mathrm{N}$-acetylglutamate synthase to 10 for ornithine carbamoyltransferase. In $S$. solfataricus, a threefold repression of enzyme formation by arginine was observed, except for $\mathrm{N}$-acetylglutamate synthase and acetylornithinase. The effect of arginine on the levels of Ta. maritima and $P$. furiosus enzymes could not be tested, since addition of yeast extract to the culture medium was necessary to obtain a reasonable growth yield (about $2 \times 10^{8}$ cells $\mathrm{ml}^{-1}$ ). However, addition of $5 \mathrm{~mm}$-arginine to a medium containing $0.05 \%$ yeast extract (about $0.05 \mathrm{~mm}$-arginine) led to a small but reproducible decrease of the level of $N$-acetylglutamate 5-phosphotransferase and argininosuccinate synthetase from Ta. maritima.

\section{Feedback inhibition by arginine}

In bacteria which synthesize arginine by the linear pathway, as observed for $S$. solfataricus, $N$-acetylglutamate synthase (Fig. 1, step 1) is the target enzyme for feedback inhibition by arginine (Vyas \& Maas, 1963; Udaka, 1966; Abdelal \& Nainan, 1979; Cunin et al., 1986). In the organisms which recycle the acetyl group by transacetylation of $N^{2}$-acetylornithine and glutamate, $N$ acetylglutamate synthase fulfils an anaplerotic function, and it is the second enzyme of the pathway, $N$ acetylglutamate 5-phosphotransferase (Fig. 1, step 2), which is feedback inhibited by arginine (Udaka, 1966; Meile \& Leisinger, 1984; Cunin et al., 1986).

Inhibition by arginine was tested for all the enzymes listed in Table 1, except argininosuccinase, by adding L-arginine (concentration range: $0 \cdot 01-100 \mathrm{mM}$ ) to the reaction mixture of the enzyme assays described above. No feedback inhibition could be detected for the first and second enzymes of the three strains which display these activities. However, arginine was found to inhibit the ornithine acetyltransferase activity of $T$. aquaticus. Inhibition was non-competitive towards acetylornithine and the apparent $K_{\mathrm{I}}$ was $1.75 \mathrm{mM} ; 90 \%$ inhibition was reached at $10 \mathrm{~mm}$-arginine. The activity of argininosuccinate synthetase of all four strains was also inhibited by arginine. Apparent $K_{\mathrm{I}}$ values for arginine of 1.4 , 0.42 and $0.25 \mathrm{~mm}$ respectively were measured for the argininosuccinate synthetase of $T$. aquaticus, Ta. maritima and $S$. solfataricus (not determined for $P$. furiosus); the arginine concentrations for $90 \%$ inhibition were 8 , 4 and $2 \mathrm{mM}$. This inhibition is probably due to a competition of arginine with citrulline for the same site on the enzyme as described for yeast argininosuccinate synthetase (Hilger et al., 1979).

\section{Biosynthesis of carbamoylphosphate}

Ornithine carbamoyltransferase, which catalyses the sixth step of arginine biosynthesis, needs carbamoylphosphate as second substrate. A carbamoylphosphate synthetase activity, which requires bicarbonate, ATP and glutamine or ammonia as substrates, was found in extracts of the two eubacteria, $T$. aquaticus and $T a$. maritima. Unlike most of the other prokaryotic carbamoylphosphate synthetases, the specific activity of these 
Table 2. Specific activities of extreme thermophilic carbamoylphosphate synthetase with glutamine and $\mathrm{NH}_{4} \mathrm{Cl}$ as substrate

Specific activities are means of at least two measurements made on independent cultures. The values for replicate assays differed from the mean by $<20 \%$.

\begin{tabular}{|c|c|c|c|c|c|}
\hline \multirow[b]{2}{*}{ Strain } & \multirow{2}{*}{$\begin{array}{l}\text { Addition to } \\
\text { minimal growth } \\
\text { medium* }\end{array}$} & \multicolumn{2}{|c|}{$\begin{array}{c}\text { Specific activity } \\
\left.\left.\text { [units (mg protein }{ }^{-1}\right)\right]\end{array}$} & \multicolumn{2}{|c|}{$\underset{(\mathrm{mM})}{\text { Apparent }} K_{\mathrm{m}}$} \\
\hline & & Glutamine & $\mathrm{NH}_{4} \mathrm{Cl}$ & Glutamine & $\mathrm{NH}_{4} \mathrm{Cl}$ \\
\hline $\begin{array}{l}\text { Thermus } \\
\text { aquaticus }\end{array}$ & $\begin{array}{l}\text { pyr, } \mathrm{NH}_{4}^{+} \\
\text {pyr, } \mathrm{NH}_{4}^{+}, \text {arg } \\
\text { pyr, } \mathrm{NH}_{4}^{+} \text {, ura } \\
\text { pyr, } \mathrm{NH}_{4}^{+} \text {, arg, ura }\end{array}$ & $\begin{array}{l}0.036 \\
0.029 \\
0 \cdot 028 \\
0.026\end{array}$ & $\begin{array}{l}0 \cdot 25 \\
0 \cdot 19 \\
0 \cdot 13 \\
0 \cdot 13\end{array}$ & 0.2 & 11 \\
\hline $\begin{array}{l}\text { Thermotoga } \\
\text { maritima }\end{array}$ & $\begin{array}{l}\text { Starch, YE } \\
\text { Starch, YE, arg }\end{array}$ & $\begin{array}{l}0 \cdot 028 \\
0 \cdot 028\end{array}$ & $\begin{array}{l}0.07 \\
0.08\end{array}$ & $1 \cdot 3$ & 9 \\
\hline
\end{tabular}

* pyr, pyruvate $(20 \mathrm{~mm})$; arg, arginine $(5 \mathrm{~mm})$; ura, uracil $\left(25 \mu \mathrm{g} \mathrm{ml}^{-1}\right)$; YE, yeast extract $(0.05 \%)$. The $\mathrm{NH}_{4}^{+}$concn was $5 \mathrm{mM} . K_{\mathrm{m}}$ values were determined at saturating levels of the other substrates.

enzymes was higher with ammonia than with glutamine as a substrate under our assay conditions (Table 2). However, the affinity for glutamine was higher than for ammonia (Table 2). Addition of arginine or uracil to the growth medium of $T$. aquaticus had little effect on the level of carbamoylphosphate synthetase (Table 2). Cumulative repression by arginine plus uracil, as described for E. coli (Piérard et al., 1965), was not observed in $T$. aquaticus. No carbamoylphosphate synthetase activity could be detected in the two archaeobacterial strains. In $S$. solfataricus, the search for carbamoylphosphate synthetase activity was made under various buffer and $\mathrm{pH}$ conditions, with glutamine, asparagine or ammonia as substrates, and by coupling the reaction with that of ornithine or aspartate carbamoyltransferase.

\section{Thermal stabilities of some arginine biosynthetic activities}

Half-life times were determined by incubating crude extracts for various times at a fixed temperature. The residual activities were measured as described in Methods. Marked stability at high temperature is a characteristic of most of these activities. Their half-life times at $80^{\circ} \mathrm{C}$ were greater than $1 \mathrm{~h}$, except for the ornithine carbamoyltransferase activity from $T$. aquaticus $\left(t_{1 / 2}: 30 \mathrm{~min}\right.$ at $80^{\circ} \mathrm{C}$ and $3 \mathrm{~min}$ at $\left.90^{\circ} \mathrm{C}\right)$ and $T a$. maritima $\left(t_{1 / 2}: 3 \mathrm{~min}\right.$ at $\left.80^{\circ} \mathrm{C}\right)$. The two latter activities could, however, be protected from heat denaturation by addition of ornithine and/or phosphate. In contrast, $S$. solfataricus and $P$. furiosus ornithine carbamoyltransferase activities proved highly thermostable $\left(t_{1 / 2}: 10 \mathrm{~h}\right.$ at $85^{\circ} \mathrm{C}$ for $S$. solfataricus, $3 \mathrm{~h}$ at $90^{\circ} \mathrm{C}$ and $30 \mathrm{~min}$ at $100^{\circ} \mathrm{C}$ for $P$. furiosus).

\section{Discussion}

In at least three of the thermophilic strains examined here, the biosynthesis of arginine proceeds via $\mathrm{N}$-acetylated intermediates as in mesophilic micro-organisms. The two strains of extreme thermophilic eubacteria, $T$. aquaticus and Ta. maritima, possess an ornithine acetyltransferase. Owing to the presence of this enzyme they are able to recycle the acetyl group from acetylornithine to glutamate and to save part of the energy required for arginine biosynthesis. An acetylornithinase activity was also detected in these two strains. However, the $T$. aquaticus acetylornithinase activity had poor affinity for $N$-acetylornithine ( $K_{\mathrm{m}}>40 \mathrm{mM}$ ) compared to that of ornithine acetyltransferase for the same substrate $\left(K_{\mathrm{m}}=0.5 \mathrm{~mm}\right)$. In Ta. maritima, the acetylornithinase activity detected was very low. These activities have presumably little or no biosynthetic function. It has been shown in yeast that the acetylornithinase measured in vitro can be ascribed to a metal-activated carboxypeptidase (Degryse, 1974). Such a carboxypeptidase could be responsible for the acetylornithinase activity measured in vitro in $T$. aquaticus and Ta. maritima extracts. These activities could also result from the action of broad substrate specificity aminoacylase or dipeptidase such as those described by Cho et al. (1987, 1988).

The archaeobacterium $S$. solfataricus lacks ornithine acetyltransferase and thus forms $\mathrm{N}$-acetylglutamate exclusively via the energetically less favourable reaction catalysed by $N$-acetylglutamate synthase, investing $1 \mathrm{~mol}$ of acetyl CoA per mol of $N$-acetyl intermediate synthesized. In contrast, methanogenic archaeobacteria have been found to use the cyclic pathway of ornithine synthesis (Meile \& Leisinger, 1984). These data show that the diversity in the biosynthesis of arginine which 
was observed previously among eubacteria also prevails for archaeobacteria.

In $P$. furiosus, none of the enzymes catalysing the steps from glutamate to ornithine could be detected. Since we were unable to grow this bacterium on a defined medium, the requirement for arginine or ornithine could not be tested. P. furiosus is an obligate anaerobe and, therefore, we cannot exclude that the failure to detect these enzymes was due to their inactivation by oxygen. However, it has been reported that the enzymes of arginine biosynthesis in obligate anaerobic methanogens are insensitive to oxygen (Meile \& Leisinger, 1984).

Repression of enzyme synthesis by arginine was observed for most of the enzymes tested in T. aquaticus and $S$. solfataricus. The changes in the levels of enzyme are less pronounced than those generally observed in mesophilic bacteria. Whereas markedly different repression ratios were obtained for the various $T$. aquaticus enzymes, a constant ratio of 3 was measured for the repressible $S$. solfataricus enzymes. Genetic data will be necessary to decide whether this behaviour is an indication of a coordinate repression mechanism similar to those known in mesophilic eubacterial operons.

The pattern of control of enzyme activity previously described, namely feedback inhibition by arginine of acetylglutamate synthase in organisms possessing the linear pathway or of the next enzyme in organisms recycling the acetyl group (Udaka, 1966; Cunin et al., 1986), was not observed in T. aquaticus. However, arginine inhibits the ornithine acetyltransferase of this organism. This pattern of inhibition is of interest since, in the cyclic pathway of ornithine synthesis, ornithine acetyltransferase may play the rôle of a key enzymic step determining the flux of arginine precursors (Fig. 1). This would be the first example of control of arginine biosynthesis at this particular step. Whether this inhibition actually plays this regulatory rôle in vivo remains to be established, since the inhibition constant of arginine $\left(K_{\mathrm{I}}=1.75 \mathrm{mM}\right)$ is relatively high as compared to the affinity of the enzyme for $N$-acetylornithine $\left(K_{\mathrm{m}}=0.5 \mathrm{mM}\right)$. One must, however, take into account that these values were determined with crude extracts and at saturating levels of glutamate. Ta. maritima and $S$. solfataricus are apparently devoid of any feedback inhibition by arginine of the early enzymes of the pathway. It will be interesting to determine whether this is a typical feature of extreme thermophiles.

Stability at high temperature is a characteristic of most of the enzymes studied, with the exception of the ornithine carbamoyltransferases of the two eubacterial strains. Yet these activities are stabilized by ornithine and phosphate, as previously observed for E. coli ornithine carbamoyltransferase (Legrain \& Stalon, 1976). The ornithine carbamoyltransferase from $T$. aquaticus has been purified to homogeneity. The enzyme consists of a trimer of identical subunits, as are the mesophilic ornithine carbamoyltransferases analysed so far (Van de Casteele et al., 1989).

Carbamoylphosphate synthetase activity was only detected in the two eubacterial strains examined. In the archaeobacteria, $S$. solfataricus and $P$. furiosus, we could not detect any carbamoylphosphate synthetase activity, although both aspartate and ornithine carbamoyltransferases were present. How these micro-organisms synthesize carbamoylphosphate remains an open question.

The involvement of carbamoylphosphate in the metabolism of extreme thermophiles raises the problem of avoiding aspecific carbamoylation of amino compounds by cyanate resulting from heat decomposition of carbamoylphosphate. In this respect, a constitutive cyanase activity, found in $T$. aquaticus extracts (unpublished observation), might play a detoxifying function. Another way of avoiding chemical carbamoylation might be to protect carbamoylphosphate from decomposition by channelling it through multi-enzyme complexes comprising the enzymes of carbamoylphosphate synthesis and utilization. Whether metabolic channelling of carbamoylphosphate occurs in extreme thermophilic micro-organisms is under investigation.

We are very grateful to Professor K. O. Stetter for his hospitality during a visit to his laboratory by M.V.C. and for the gift of Ta. maritima and $P$. furiosus strains.

This work was supported by grant no. 2.9003.88 from the Belgian Fund for Joint Basic Research, by a Concerted Research Action financed by the Belgian Government and by a Research Contract no. BAP-0345-B from the Commission of the European Communities. M.V.C. is Aspirant of the National Fund for Scientific Research (Belgium).

\section{References}

Abdelal, A. T. \& Nainan, O. V. (1979). Regulation of $N$ acetylglutamate synthesis in Salmonella typhimurium. Journal of Bacteriology 137, 1040-1042.

BALCH, W. E. \& WolfE, R. S. (1976). New approach to the cultivation of methanogenic bacteria: 2-mercaptoethanesulfonic acid (HSCoM)-dependent growth of Methanobacterium ruminantium in a pressurized atmosphere. Applied and Environmental Microbiology 32, 781-791.

Cho, H. Y., Tanizawa, K., Tanaka, H. \& Soda, K. (1987). Thermostable aminoacylase from Bacillus thermoglucosidus: purification and characterization. Agricultural and Biological Chemistry 51, 2793-2800.

Cho, H. Y., Tanizawa, K., Tanaka, H. \& Soda, K. (1988). Thermostable dipeptidase from Bacillus stearothermophilus: its purification, characterization, and comparison with aminoacylase. Journal of Biochemistry 103, 622-628.

Cunin, R., Glansdorff, N., Piérard, A. \& Stalon, V. (1986). Biosynthesis and metabolism of arginine in bacteria. Microbiological Reviews 50, 314-352.

DEGRYSE, E. (1974). Evidence that yeast acetylornithinase is a carboxypeptidase. FEBS Letters 43, 285-288. 
Degryse, E., Glansdorff, N. \& Piérard, A. (1976). Arginine biosynthesis and degradation in an extreme thermophile, strain ZO5. Archives Internationales de Physiologie et de Biochimie 84, 599-601.

Degryse, E., Glansdorff, N. \& Piérard, A. (1978). A comparative analysis of extreme thermophilic bacteria belonging to the genus Thermus. Archives of Microbiology 117, 189-196.

Fiala, G. \& Stetter, K. O. (1986). Pyrococcus furiosus sp. nov. represents a novel genus of marine heterotrophic archaebacteria growing optimally at $100^{\circ} \mathrm{C}$. Archives of Microbiology 145, 56-61.

Fiala, G., Stetter, K. O., Jannasch, H. W., Langworthy, T. A. \& MADON, J. (1986). Staphylothermus marinus sp. nov. represents a novel genus of extremely thermophilic submarine heterotrophic archaebacteria growing up to $98^{\circ} \mathrm{C}$. Systematic and Applied Microbiology 8, 106-113.

HAAS, D., Kurer, V. \& Leisinger, T. (1972). N-Acetylglutamate synthase of Pseudomonas aeruginosa. An assay in vitro and feedback inhibition by arginine. European Journal of Biochemistry 31, 290-295.

HaAs, D., Holloway, B. W., SChamböCK, A. \& Leisinger, T. (1977).

The genetic organization of arginine biosynthesis in Pseudomonas aeruginosa. Molecular and General Genetics 154, 7-22.

Hilger, F., Simon, J. P. \& Stalon, V. (1979). Yeast argininosuccinate synthetase. Purification; structural and kinetic properties. European Journal of Biochemistry 94, 153-163.

Huber, R., Langworthy, T. A., König, H., Thomm, M., Woese, C. R., SLeYtr, U. W. \& Stetter, K. O. (1986). Thermotoga maritima sp. nov. represents a new genus of unique extremely thermophilic eubacteria growing up to $90^{\circ} \mathrm{C}$. Archives of Microbiology 144, 324-333.

Legrain, C. \& Stalon, V. (1976). Ornithine carbamoyltransferase from Escherichia coli W. Purification, structure and steady-state kinetic analysis. European Journal of Biochemistry 63, 289-301.

Legrain, C., Glansdorff, N. \& Piérard, A. (1989). Enzymes of arginine biosynthesis in a thermophilic archaebacterium, Sulfolobus solfataricus. Archives Internationales de Physiologie et de Biochimie 97 , B103.

LEISINGER, T. \& HAAS, D. (1975). N-Acetylglutamate synthase of Escherichia coli : regulation of synthesis and activity by arginine. Journal of Biological Chemistry 250, 1690-1693.

MEILE, L. \& LeISINGER, T. (1984). Enzymes of arginine biosynthesis in methanogenic bacteria. Experientia 40, 899-900.
Piérard, A., Glansdorff, N., Mergeay, M. \& Wiame, J. M. (1965). Control of the biosynthesis of carbamoylphosphate in Escherichia coli. Journal of Molecular Biology 14, 23-36.

Piérard, A., GlansdorfF, N. \& YashPhe, J. (1972). Mutations affecting uridine monophosphate pyrophosphorylase or the $\arg R$ gene in Escherichia coli. Effects on carbamoylphosphate and pyrimidine biosynthesis and on uracil uptake. Molecular and General Genetics 118, 235-245.

Stalon, V., Ramos, F., Piérard, A. \& Wiame, J. M. (1972). Regulation of the catabolic ornithine carbamoyltransferase of Pseudomonas fluorescens. A comparison with the anabolic transferase and with a mutationally modified catabolic transferase. European Journal of Biochemistry 29, 25-35.

STETTER, K. O. (1986). Diversity of extremely thermophilic archaebacteria. In Thermophiles: General, Molecular and Applied Microbiology, pp. 39-74. Edited by T. D. Brock. New York: John Wiley.

Stetter, K. O., König, H. \& Stackebrandt, E. (1983). Pyrodictium gen. nov., a new genus of submarine disc-shaped sulphur reducing archaebacteria growing optimally at $105^{\circ} \mathrm{C}$. Systematic and Applied Microbiology 4, 535-551.

TheIL, E. C., Forsyth, G. W. \& JoNEs, E. E. (1969). Expression of the arginine regulon of Escherichia coli W: evidence for a second regulatory gene. Journal of Bacteriology 99, 269-273.

UDAKA, S. (1966). Pathway-specific pattern of control of arginine biosynthesis in bacteria. Journal of Bacteriology 91, 617-621.

Van de Casteele, M., Legrain, C., Piérard, A. \& Glansdorff, N. (1989). Purification and characterization of ornithine carbamoyltransferase of the extreme thermophilic eubacterium Thermus aquaticus. Archives Internationales de Physiologie et de Biochimie 97, B115.

VoGel, H. J. \& MCLellan, W. L. (1970). Acetylornithinase (Escherichia coli). Methods in Enzymology 17A 265-269.

VyAS, S. \& MAAS, W. K. (1963). Feedback inhibition of acetylglutamate synthetase by arginine in Escherichia coli. Archives of Biochemistry and Biophysics 100, 542-546.

WOESE, C. R. (1987). Bacterial evolution. Microbiological Reviews 51, 221-271. 